
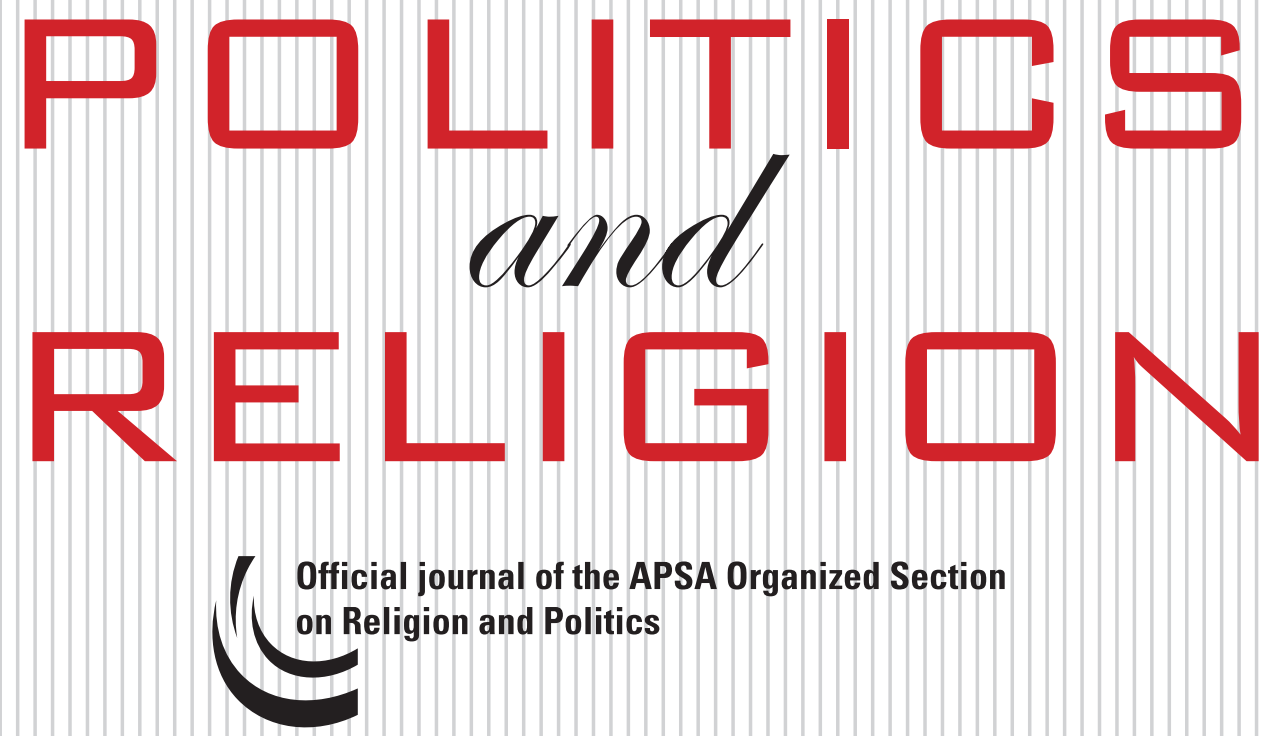

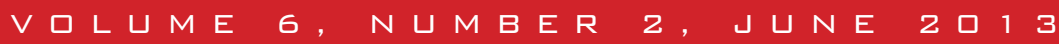




\section{POLITICS AND RELIGION}

\section{CO-EDITORS}

Paul A. Djupe

Department of Political Science

Denison University

P.O. Box 810

Granville, OH 43023

Telephone: (740) 587-6310

Fax: (740) 587-6601

E-mail: politicsandreligionjournal@gmail.com
Angelia Wilson

Department of Political Science

The University of Manchester

Oxford Road

Manchester M13 9PL

United Kingdom

Telephone: +44 (0) 1613066000

E-mail: politicsandreligionjournal@gmail.com

\section{BOOK REVIEW EDITOR}

Andrew Murphy

Department of Political Science

Rutgers University

89 George Street

New Brunswick, NJ 08901

E-mail: prbookreview@gmail.com

\section{EDITORIAL BOARD}

Cynthia Burack, Ohio State University, USA

Simone Chambers, University of Toronto, Canada

Daniel Dreisbach, American University, USA

Joel Fetzer, Pepperdine University, USA

Jo Renee Formicola, Seton Hall University, USA

Jonathan Fox, Bar-Ilan University, Israel

Anna Gryzmala-Busse, University of Michigan, USA

Frances Hagopian, Harvard University, USA

Jeffrey Haynes, London Metropolitan

University, $U K$

Thomas Heilke, University of Kansas, USA

Amaney Jamal, Princeton University, USA

Robert Jones, Public Religion Research Institute, USA

Ahmet T. Kuru, San Diego State University, USA
Geoff Layman, University of Notre Dame, USA Philip Manow, University of Bremen, German

Liz Oldmixon, University of North Texas, USA Michael Leo Owens, Emory University, USA

Daniel Philpott, University of Notre Dame, USA

Sabrina Ramet, Norwegian University of Science \& Technology, Norway

Sultan Tepe, University of Illinois at Chicago, USA

Colin Tyler, University of Hull, $U K$

Ken Wald, University of Florida, USA

Clyde Wilcox, Georgetown University, USA

Erin K.Wilson, University of Groningen, Netherlands

Fenggang Yang, Purdue University, USA

Politics and Religion, is an international journal publishing high quality peer-reviewed research on the multifaceted relationship between religion and politics around the world. The scope of published work is intentionally broad and we invite innovative work from all methodological approaches in the major subfields of political science, including international relations, American politics, comparative politics, and political theory, that seeks to improve our understanding of religion's role in some aspect of world politics. The Editors invite normative and empirical investigations of the public representation of religion, the religious and political institutions that shape religious presence in the public square, and the role of religion in shaping citizenship, broadly considered, as well as pieces that attempt to advance our methodological tools for examining religious influence in political life. 


\section{Politics and Religion}

\section{Volume 6, Number 2, June 2013}

\section{ARTICLES}

Religious Group Cues and Citizen Policy Attitudes in the United States

Todd Adkins, Geoffrey C. Layman, David E. Campbell, and John C. Green

Using Matching to Investigate the Relationship between Religion and Tolerance

Ryan Burge

Demand for God and Government: The Dynamics of Religion and Public Opinion

Philip Habel and J. Tobin Grant

Religion, Rational Political Theory, and the 2008 Presidential Election

Jungyun Gill and James DeFronzo

Faith-Based Interventions for At-Risk Latino Youths:

A Study of Outcomes

Stephen V. Monsma and Corwin E. Smidt

Religion and Perceptions of Candidates' Ideologies in

United States House Elections

Matthew L. Jacobsmeier

Belonging in a "Christian Nation": The Explicit and Implicit

Associations between Religion and National Group Membership

Carly M. Jacobs and Elizabeth Theiss-Morse

Giving Up on the Founding: The Separation of Church and

State and the Writing of Establishment Clause History

Christopher S. Grenda 


\section{BOOK REVIEWS}

Stretching the Parameters of Religion in the Revolutionary Era Reviewed by Jonathan Den Hartog

Church and State: Religious Nationalism and State Identification in Post-Communist Romania. By Cristian Romocea

REviewed By Lucian Turcescu

In the Whirlwind: God and Humanity in Conflict.

By Robert A. Burt

REviEwED BY Mark J. Lutz

Religion and Democracy in the United States: Danger or Opportunity? Edited by Alan Wolfe and Ira Katznelson Reviewed by Paul A. Djupe

After Secularism: Rethinking Religion in Global Politics.

By Erin K. Wilson

Reviewed By Amélie Barras 


\section{Politics and Religion INSTRUCTIONS FOR CONTRIBUTORS}

- Manuscripts may be submitted to either of the Co-Editors.

- Manuscripts must be no longer than 10,000 words including text, tables and figures, references and appendices. The entire manuscript (including notes and references) must be double-spaced, with one-inch margins and 12-point font.

- The author must include a separate title page, with his or her full contact information (including email address, telephone number and institutional affiliation). All identifying information must be removed from the manuscript.

- A second page must include an abstract of no more than 200 words.

- Placement of tables or figures should be cited in the text. The publisher will be responsible for placing artwork, tables or figures, as well as converting endnotes to footnotes.

- Appendices, tables, and figures should be numbered consecutively throughout the article and be included on separate pages appearing after the reference section. Figures should be ready for photographic reproduction; they cannot be redrawn by the publisher. Charts, graphs, or other artwork should be professional rendered or computer generated. Photographs should be clearly printed and should remain legible after a 50\% reduction.

- References and notes should conform to the APSA Style Manual. Authors should include full volume, issue, and page numbers for references. Author's acknowledgments or other personal notes will appear as an unnumbered note at the foot of the page. Notes should be numbered consecutively throughout the article. Numbered notes should appear at the end of the sentence. If multiple texts are cited in a sentence they should appear as one consolidated note at the end of the sentence.

- Endnotes should be employed (rather than footnotes).

- All figure captions should be typed on a separate page (or pages), rather than on the figures themselves (which are camera-ready art) so that they can be copyedited.

Originality and copyright: Papers with multiple authors are reviewed with the assumption that all authors concur with its submission. A Copyright Transfer Agreement, with certain specified rights reserved by the author, must be signed and returned to the Editor by senior authors of accepted manuscripts, prior to publication. Politics and Region does not accept manuscripts for review that are under review elsewhere, previously published or already committed for publication.

For general guidelines for preparing a manuscript for submission, please refer to the APSA Style Manual for Political Science (rev. ed. 2001) for citation, footnotes, references, and other style issues. Please note, in particular, the statement on gender specific language (15). 